\title{
Intelligent Online e-Learning Systems: A Comparative Study
}

\author{
Gopal Sakarkar \\ MCA Dept., RCOEM, Nagpur, \\ Maharashtra, India
}

\author{
S.P.Deshpande, PhD. \\ Head, MCA Department, \\ PGDCS\&T, HVPM \\ Amravati, Maharashtra, India
}

\author{
V. M. Thakare, PhD. \\ Professor, P.G. Department, \\ S.G.B.Amravati University \\ Amravati, Maharashtra, India
}

\begin{abstract}
The growth in the field of Information Technology (IT) has been very fast in last few decades and the various applications depending on IT are also changing very drastically. One of the very popular IT applications is online teaching and learning. The main focus of this article is to survey the various online elearning architectures and then make a comparison among them. Based on the analytical, comparative studies of these various architectures, we are able to provide certain suggestions about the limitations that were observed. Further on, we emphasize some of the research challenges and design issues that have been followed in order to make fruitful improvement in the intelligent online e-learning architecture system to provide the cultural aspects of online classrooms.
\end{abstract}

\section{General Terms}

Comparative Study, Online E-learning Systems, Semantic Web Technology, Intelligent Mobile Agent.

\section{Keywords}

Intelligent Agent, e-learning, Semantic Web technology, Ontology, Online e-learning Models, Learning Management Systems.

\section{INTRODUCTION}

Information sharing and retrieving is a current trend of online society. Somehow, the Web-based technology is providing this functionality, but due to increasing web users every days and increasing their exact information retrieving habit, it is very challenging task for web site provider to make available the user-specific accurate information, on demand and as per requirement without any prior knowledge of that web user. After studying the current working of client-server based web service architecture, it has been found that all information available on the websites is heterogeneous i.e. data having a different format like audio, video, text, multimedia etc. Also this information is present in disparate places.

Intelligence is a special characteristic gifted to a human being and Artificial Intelligence is property that human have being trying to put into computer system from the last fifty years, and journey is still continuing.

To provide the information in an intelligent way, a semantic web technology, a new future work of web technology was proposed by Mr. Tim Berners Lee, President W3C.The Semantic Web is a new WWW architecture that supports not only Web content, but also associated formal semantics. Using semantic web, information is given in a well-defined meaning that enables, in better way, computers and people to work in cooperation. The idea of semantic web is to leave most of the tasks and decisions to machines [1]. It is a mechanism to make web based system more intelligent.

But to develop an effective semantic web technology, ontology needed to be design. Ontology describes some application-relevant part of the world in a machineunderstandable format. Ontology is considered as a tool that defines additional meanings that are tagged to web pages and makes them available to be used by software agents and web applications [2].

The trend of modernization has entered the online e-learning system also that it is been used for higher education through the Internet. The conventional online e-learning which provides learning information only in the form of electronic data, is just a static information displaying web-based system or using standalone personal computer applications assemble on CD/DVD. But the current era of information system can go one step ahead, in the sense that information in text or in multimedia format is not only displayed but displayed in an intelligent way, as per the knowledge level of online learner, just like human instructor.

The current paper is organized as

Various researchers views about online e-learning and semantic web services is describe in section 2, The important online e-learning model architecture is describe in section 3 , Comparative study of various online e-learning architectures is summaries in section 4, Research challenges and design issues for improving online e-learning system is proposed in section 5 and finally authors conclude the work in section 6 .

\section{RELATED WORK}

The efficiency of online e-learning is improve by evaluating the student's performance, offering feedback to the tutor and providing reliable query response system with a combination of computational intelligence of online e-learning system and prosperities of intelligent mobile agent system. Authors proposed the personalization agent used in an online elearning system to retrieve learning materials based on cognitive style, personal preferences and prior knowledge [3]. Authors designed the Multi-Agent-Based M-Learning System Architecture which is based on 3-tier structure that involves the mobile devices, the base station and the content centre. In this a mobile agent continuously monitors the learner's actions for identifying optimal learning conditions and notes the weak knowledge area of user. The architecture supports the process of composing personalized content for an individual mobile user, rapid course development and collaboration [4].The architecture for simplifying and automating the process of creating the domain model for an intelligent online e-learning system, which is based on knowledge representation of educational resources using World Wide Web, was described in [5].

One of the basic challenge faced by researchers is to develop an effective online e-learning system requiring a different parameters, like query expansion, learner's profile, web log preprocessing, web knowledge discovery and opinion, selfmotivated, self-discipline, communicative and ability to work in multitasking that all these facilities provide in one architecture [6]. An Agent Based Intelligent System (ABIS) is a novel set of applications which will be developed for the online e-learning. Authors have surveyed various current trends and techniques used to represent knowledge. The proposed architecture is a set of methodologies and data- 
mining techniques by aggregating and customizing the state of the art research in online e-learning domain [7]. One of the benefits provided by an agent based online e-learning system is it can continuously retrieve the most up-to-date educational materials available when creating customized lesson plans for learners. Another advantage of an agent based online elearning system is that it can assist instructors in monitoring learner progress and facilitate interactions between the instructor and learners that are struggling with a particular topic [8].

The problem in the existing web based online e-learning system is the lack of personalization due to weak semantic learning resources. Insufficient semantic parts in web services technology make it difficult for finding suitable web services according to the user's request was find out in[9].

To overcome such problem, the web requires an intelligent system, which can be implemented using Semantic web, in which computer can serve as an intelligent agent and then compute the meaningful information just like human brain.

\section{STANDARD ONLINE E-LEARNING MODELS}

An online e-learning is a very challenging research platform, some of the commonly used standard online e-learning models are (a) IEEE Learning Technology Systems Architecture (LTSC), (b) Sharable Content Object Reference Model (SCORM), (c) Blackboard and (d) Moodle.

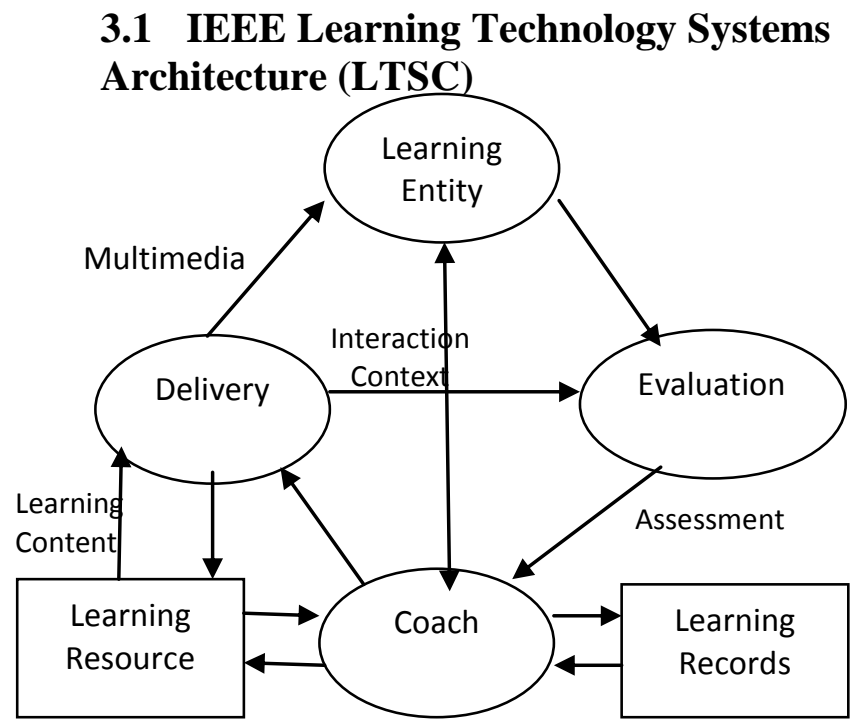

Fig 1: Learning Technology Systems Architecture

This IEEE Learning Technology Systems Architecture (LTSC) [10] model basically has six components as shown in Fig.1. Learner entity is GUI for student or learner who wants to access the information from online e-learning system. Coach acts as a heart of this model. It provides the learning materials, assessment information, answering the queries etc. Delivery component is used to deliver the study material in well and predefine format using any multimedia applications. Learning resources component has catalog information, which decides what information has been provide to a learner via delivery section. Most important component of this model is evaluation section that continuously evaluates a student's behavior, progress in study by evaluation a test, assignment or any type of examination taken by the system. The last section i.e. learner records is keeps the information of learner's profile, his/her current and historical information and its personal as well as academic information.

\subsection{Sharable Content Object Reference Model (SCORM)}

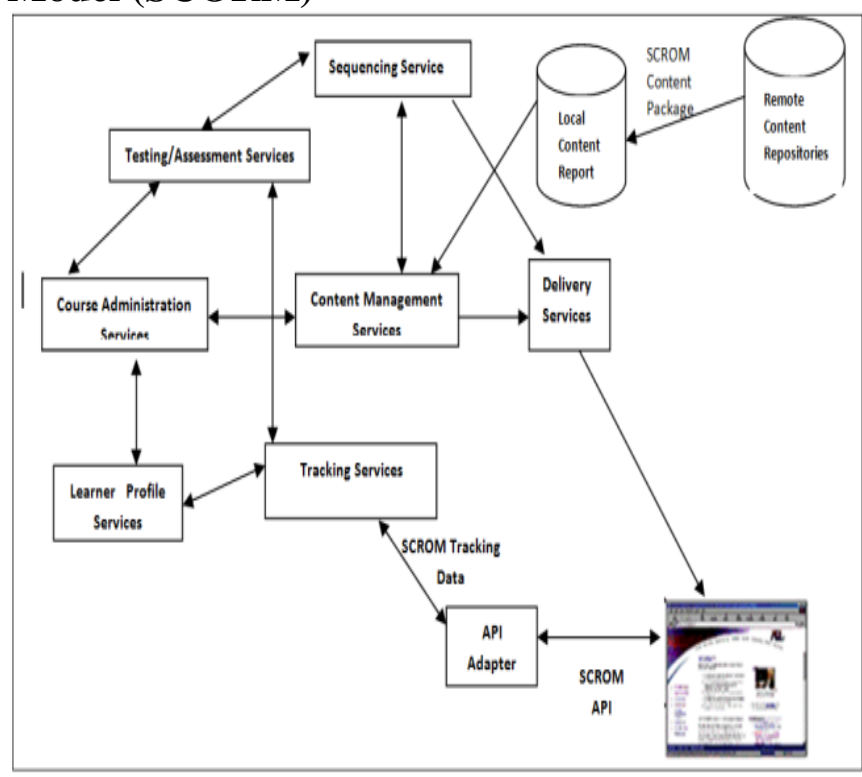

Fig2: Sharable Content Object Reference Model

This Sharable Content Object Reference Model (SCORM) [11] architectural model is very popular among the web-based online e-learning systems as shown in Fig.2. The additional service provided by this model among others is content management system. The system provider has a flexibility to make available the content of learning material according to user. It also has an API adapter which helps to provide application level interface that is independent of programming languages. It provides the information using web browser only.

\subsection{The blackboard}

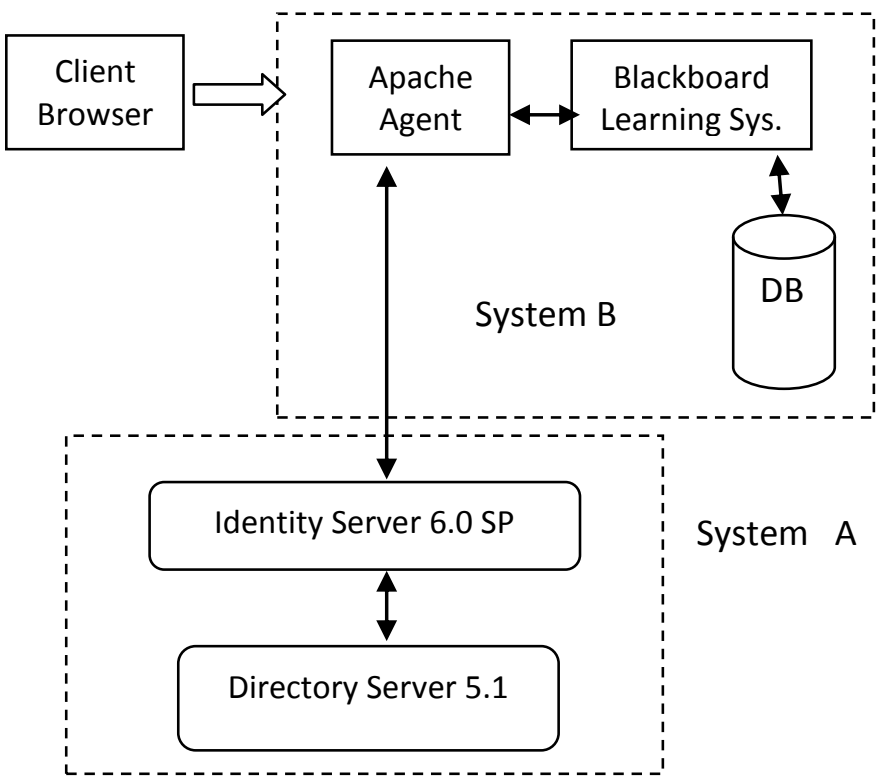

Fig 3: The Blackboard Architecture 
The blackboard [12] is also a web-based online e-learning system. One of the advantages in this system that it used a concept of an Agent. Eventhough its Agent concept is not so effective. It's a new approach for adding an intelligent concept using an agent technology is worth appreciating. It has client-server architecture for information sharing as shown in Fig.3. It provides flexibility to instructor for uploading as much as is required information about the subject using any multimedia format. This architecture is divided into two parts. The first is identity server which performs the authentication and authorization of login user. Then it redirects the authorized user to blackboard learning system, which provides all e-learning material for studying a particular subject.

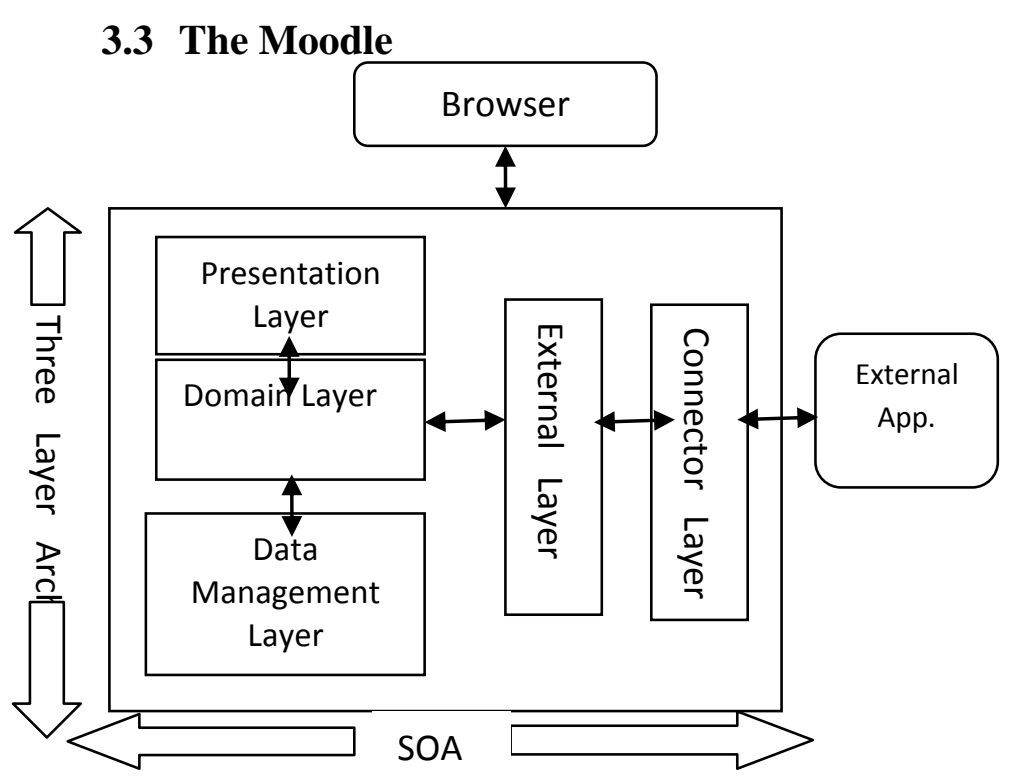

Fig 4: The Moodle Architecture

Table1: Comparative study of different online e-learning architectures and services.

\begin{tabular}{|c|c|c|c|c|c|}
\hline SrNo & $\begin{array}{l}\text { Online e-Learning } \\
\text { Architectures }\end{array}$ & Learning Objects & $\begin{array}{c}\text { Advance Technology for } \\
\text { Knowledge } \\
\text { Representation } \\
\end{array}$ & Additional Features & Drawbacks (if any) \\
\hline 1 & e-AULA[14] & Semantic metadata & Ontology, RDF & Personalization & $\begin{array}{l}\text { Non-Standardization in } \\
\text { the pedagogical ontology }\end{array}$ \\
\hline 2 & e-LKG[15] & ------ & Open source & $\begin{array}{c}\text { Improving engineering } \\
\text { students mathematical } \\
\text { skill }\end{array}$ & ------- \\
\hline 3 & $\begin{array}{l}\text { Adaptive e-learning } \\
\text { System[16] }\end{array}$ & $\begin{array}{l}\text { Item Response } \\
\text { Theory }\end{array}$ & Ontology & Base on Humanization & ------- \\
\hline 4 & ADL-SCORM[17] & $\begin{array}{l}\text { Reusability of } \\
\text { previous content } \\
\text { object }\end{array}$ & $\begin{array}{c}\text { XML,JAVASCRIPT,Agent } \\
\text { Technology }\end{array}$ & $\begin{array}{l}\text { Allowed mobile devices } \\
\text { Access }\end{array}$ & $\begin{array}{c}\text { Lack of interactive } \\
\text { interface and intelligent } \\
\text { approach }\end{array}$ \\
\hline 5 & $\begin{array}{l}\text { Distributed and } \\
\text { Services Oriented } \\
\text { Architecture[18] }\end{array}$ & Web Service & WSDL,SOAP,UDDI, XML & Interoperability & ------- \\
\hline 6 & $\begin{array}{l}\text { Conceptual e- } \\
\text { learning Framework } \\
\text { CELF[19] }\end{array}$ & Self-directed & ------- & $\begin{array}{l}\text { Andragogy-the art and } \\
\text { science of helping adults } \\
\text { learning }\end{array}$ & $\begin{array}{l}\text { Research result has not } \\
\text { been empirically tested }\end{array}$ \\
\hline 7 & AEHS-LS[20] & $\begin{array}{l}\text { Implement concept } \\
\text { of relationship }\end{array}$ & Apache, MySQL, PHP & $\begin{array}{l}\text { Used of VARK } \\
\text { questionnaire }\end{array}$ & ------- \\
\hline
\end{tabular}




\begin{tabular}{|c|c|c|c|c|c|}
\hline SrNo & $\begin{array}{c}\text { Online e-Learning } \\
\text { Architectures }\end{array}$ & Learning Objects & $\begin{array}{c}\text { Advance Technology for } \\
\text { Knowledge } \\
\text { Representation } \\
\end{array}$ & Additional Features & Drawbacks (if any) \\
\hline 8 & $\begin{array}{l}\text { Auto recommended } \\
\text { based system } \\
\text { Architecture[21] }\end{array}$ & $\begin{array}{l}\text { Profile based } \\
\text { recommendation }\end{array}$ & AJAX,XML, JavaScript & $\begin{array}{l}\text { Implemented in } \\
\text { distributed environments }\end{array}$ & $\begin{array}{l}\text { Implicit or Explicit } \\
\text { recommendation is } \\
\text { necessary }\end{array}$ \\
\hline 9 & AeL[22] & Multimedia Tools & $\begin{array}{c}\text { XML,SVG, Mathematical } \\
\text { Mark-up } \\
\text { Language(MathML) }\end{array}$ & $\begin{array}{c}\text { Portable on mobile } \\
\text { devices }\end{array}$ & 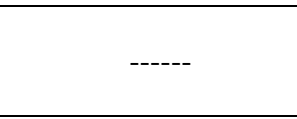 \\
\hline 10 & FABULA[23] & $\begin{array}{l}\text { Services based } \\
\text { online e-learning }\end{array}$ & $\begin{array}{l}\text { Multi-Agent System, } \\
\text { Ontology }\end{array}$ & $\begin{array}{c}\text { Mobile device support, } \\
\text { AGORA for performing } \\
\text { cooperative work by } \\
\text { Agent }\end{array}$ & ------ \\
\hline 11 & $\begin{array}{l}\text { Collaborative- } \\
\text { ELMS[24] }\end{array}$ & $\begin{array}{c}\text { collaborative } \\
\text { learning approach }\end{array}$ & $\begin{array}{l}\text { Multi-Agent System, } \\
\text { Ontology }\end{array}$ & $\begin{array}{c}\text { It used } i^{*} \text { framework } \\
\text { model for collaborative } \\
\text { learning }\end{array}$ & ------- \\
\hline 12 & $\begin{array}{l}\text { Voting based } \\
\text { e-learning } \\
\text { Architecture[25] }\end{array}$ & $\begin{array}{l}\text { By Voting } \\
\text { Response }\end{array}$ & $\begin{array}{l}\text { Autonomous Agent, } \\
\text { XML,RMI, JavaSpace and } \\
\text { JATLite }\end{array}$ & Personalization & $\begin{array}{l}\text { Course selecting } \\
\text { procedure depend on } \\
\text { whether or not another } \\
\text { course is running }\end{array}$ \\
\hline
\end{tabular}

After comparing the different e-learning architectures and services, it has been found that most of intelligent e-learning systems are expected to be domain independent and task independent .

\section{RESEARCH CHALLENGES AND DESIGN ISSUES}

- After taking a broad review of these various online elearning architectures, some of the challenges for developing an effective online learning system are found to be:

- To develop intelligent mobile agent architecture for semantic web based online e-learning system.

- To put as much knowledge as possible into the mobile agent

- To make mobile agents behave more intelligently and take advantage of the semantic web technology.

- To develop an online e-learning system which will be adaptive, collaborative and standardize?

- To make online e-learning system more Personalized and Intelligent.

- To use recommendation agent to recommend the appropriate information and also to recommend other associative e-learners in the teaching learning process.

- Proper knowledge information categorization on the user's learning ability.

\subsection{Design Issues}

- Online e-learning system should provide visual demonstration of topics.

- It should have statistical analysis before using that particular online topic and also provide some opinions about topic.

- It should have ability to collaborate and innovate new topic information.

- It should use Artificial Intelligence with voice recognition to interact with user.

- It should have a learning ability.

- It should provide answers from internal database, Web, Wiki, previous conversation.
- It should search information from several online databases, like Google, Ask.com, Bing and others.

\section{CONCLUSION}

As research in online e-learning is an ongoing process and also the requirement of online learners change every day .Also every online e-learning architecture has been found to have with some of the limitations. It is very challenging task for the service providers and researchers to fulfill all requirement of learners. One of the solutions about this scenario is the combination of Semantic Web technology and intelligent software agent having the property of learner's personalization. With the help of them, it will be possible to develop effective and real life online e-learning applications.

\section{REFERENCES}

[1] Berners-Lee, T., Hendler, J., and Lassila, O., (2001), "The Semantic Web", The Scientific American: pp. 3443.

[2] Hamed Hassanzadeh1 and MohammadReza Keyvanpour (2011), "A Machine Learning Based Analytical Framework for Semantic Annotation Requirement", International Journal of Web \& Semantic Technology (IJWesT) Vol.2, No.2, pp.27-38

[3] Sivakumar,K.Vivekanandan,B.Arthi,S.Sandhya,Veenas Katta(2011) , "Incorporating Agent Technology for Enhancing the Effectiveness of e-learning System" ,IJCSI International Journal of Computer Science Issues, Vol. 8, Issue 3 ,pp.454-460

[4] Hasan Omar Al-Sakran ,Fahad Bin Muhaya,Irina Serguievskaia, "Multi Agent-Based M-Learning System Architecture" ,IEEE Region 8 SIBIRCON-2010, Irkutsk Listvyanka, Russia, July 11-15, 2010 ,pp.870-875

[5] S.Prakasam,Prof.R.M.Suresh (2010), “An agent-based Intelligent System to enhance e-learning through Mining Techniques", International Journal on Computer Science and Engineering Vol. 02, No. 03, pp. 759-763

[6] Axita Shah, Sonal Jain (2011), "An Agent based Personalized Intelligent e-learning", International Journal of Computer Applications (0975 - 8887) Volume 20 No.3, pp.-40-45 
[7] Suraya Masrom, Abdullah Sani Abd. Rahman(2009), "An Adaptation of Agent-Based Computer- Assisted Assessment into e-learning Environment", IJEIT Issue 3, Volume 3, pp.163-170

[8] Dawn G. Gregg (2007), "Online e-learning agents", The Learning Organization Vol. 14 No. 4, pp. 300-312

[9] Jamuna Rani S, Marie Stanislas Ashok , Palanivel K.,"Adaptive Content for Personalized e-learning using Web Service and Semantic Web", International conference on Intelligent Agent and Multi Agent Sytem, 2009,IEEE

[10] http://www.ieeeltsc.org

[11] http://scorm.com/

[12]http://www.blackboard.com/

[13] http://moodle.org/

[14] Pilar Sancho,Iván Martínez,Baltasar FernándezManjón(2005), "Semantic Web Technologies Applied to e-learning Personalization in <e-aula>",Journal of Universal Computer Science, vol. 11, no.9, 14701481,pp.1470-1481

[15] Natalia Boal1,José Manuel Correas,José Jorge Gil,Pablo López ,María Luisa Sein-Echaluce, "E-Learning systems as a Combination Between technology and Education Methodologes".

[16] E.Kovatcheva, R.Nikolov, "An adaptive feedback approach for e-learning systems", IMCL2008 Conference, Jordan (2008),pp.1-3

[17] Ali Shemshadi, Javad Soroor, Mohammad J. Tarokh , "An Innovative Framework for the New Generation of SCORM 2004 Conformant Online e-learning Systems", IEEE Fifth International Conference on Information Technology: New Generations, 2008, pp.949-954

[18] Ahmad Luthfi (2010), "Intelligent Learning Objects (LOs) Through Web Services Architecture", International Indonesia Journal, Vol.2/No.1, pp.17-22

[19] Fletcher H. Glancy,Susan K. Isenberg, “A Conceptual Elearning Framwork", European, Mediterranean \& Middle Eastern Conference on Information Systems 2011 (EMCIS2011) May 30-31 2011,pp.636-650.

[20] Yasir Eltigani Ali Mustafa and Sami Mohamed Sharif (2011),"An approach to Adaptive e-learning Hypermedia System based on Learning Styles (AEHS-LS): Implementation and evaluation", International Journal of Library and Information Science Vol. 3(1), pp. 15-28, pp.16-28

[21] Abdallah Gomah, Samir Abdel, Rahman Amr ,Badr Ibrahim Farag (2011), "An Auto-Recommender Based Intelligent e-learning System", IJCSNS International Journal of Computer Science and Network Security, VOL.11 No.1, pp.67-70
[22] Lucian Lupu Dima, Eduard Edelhauser, Andreea Ionica, "E-lEarning Platforms In Romanian Higher Education", Annals of the University of Petroşani, Economics, 10(1), $2010,137-148$

[23] B A. Khan,"FABULA Platform for Active e-learning in Mobile Networks"

[24] Zhi Liu,Hai Jin, Zhaolin Fang, "Collaborative Learning in Online e-learning based on Multi-Agent Systems", Proceedings of the 10th International Conference on Computer Supported Cooperative Work in Design,IEEE 2006.

[25] Ali M. Aseere, Enrico H. Gerding,David E. Millard, “A Voting-Based Agent System for Course Selection in elearning" ,IEEE/WIC/ACM International Conference on Web Intelligence and Intelligent Agent Technology, 2010.

\section{AUTHORS PROFILE}

Mr. Gopal Sakarkar holding a Master Degree in Computer Applications and Bachelor Degree in Computer Science from S.G.B. Amravati University, India. He is currently working as Asst. Prof. in department of Master in Computer Applications. He has published 5 research papers in various IEEE International Conferences and in International Journals. He had delivered a guest speech at Universidad Nacional Experimental Politécnica "Antonio José de Sucre" (UNEXPO), Caracas - Venezuela

He was also representing as core committee member during 2nd International Computer Science On-Line Conference 2012 at Czech Republic. His research areas are Intelligent Agent, Mobile Agent, Semantic Web, Ontology, Facerecognition and e-learning systems.

Dr. S. P. Deshpande is currently working as Associate Professor at Post Graduate Department of Computer Science \& Technology, MCA at Shree, H. V. P .Mandal's Amravati since last 15 years. He has published 25 papers in various national \& International conferences \& 10 papers in International journals. He has guided more than 100 students at Post Graduate level. His interest of research is DBMS, Data Mining, Web based technologies, AI

Dr. V. M. Thakare is Professor and Head at Department of Computer science S.G.B.Amravati University, Amravati, India. He has received M.E. (Advance Electronics from Amravati University), P.G. DCM, from IICM, Ahamadabad and $\mathrm{Ph} . \mathrm{D}$. in Computer Science. He has been invited as a Keynote Speaker, Invited Speaker, Session Chair and Reviewer for more than 25 International \& National Conferences. He has been actively involved in the research in the area of Robotics and AI, Computer Architectures, ICT, SE ect. 